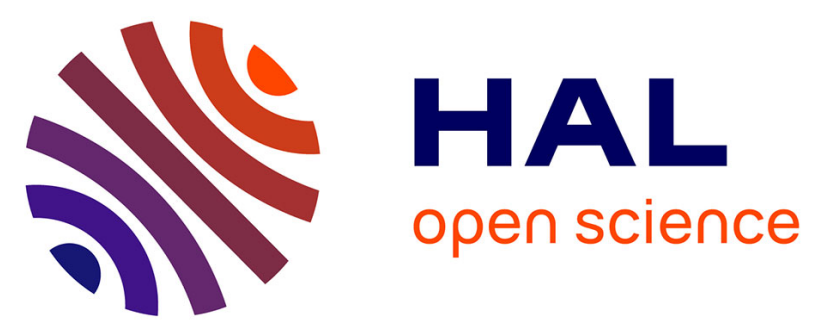

\title{
Receptor for Advanced Glycation End Products is Involved in Platelet Hyperactivation and Arterial Thrombosis during Chronic Kidney Disease
}

Jérémy Ortillon, Nathalie Hézard, Karim Belmokhtar, Charlotte Kawecki, Christine Terryn, Guenter Fritz, Alexandre Kauskot, Ann Marie Schmidt, Philippe Rieu, Philippe Nguyen, et al.

\section{To cite this version:}

Jérémy Ortillon, Nathalie Hézard, Karim Belmokhtar, Charlotte Kawecki, Christine Terryn, et al.. Receptor for Advanced Glycation End Products is Involved in Platelet Hyperactivation and Arterial Thrombosis during Chronic Kidney Disease. Thrombosis and Haemostasis, 2020, 120 (09), pp.13001312. 10.1055/s-0040-1714101 . hal-02991950

\section{HAL Id: hal-02991950 https://hal.science/hal-02991950}

Submitted on 16 Nov 2020

HAL is a multi-disciplinary open access archive for the deposit and dissemination of scientific research documents, whether they are published or not. The documents may come from teaching and research institutions in France or abroad, or from public or private research centers.
L'archive ouverte pluridisciplinaire HAL, est destinée au dépôt et à la diffusion de documents scientifiques de niveau recherche, publiés ou non, émanant des établissements d'enseignement et de recherche français ou étrangers, des laboratoires publics ou privés. 


\section{Thrombosis and Haemostasis \\ ssverosous \\ International joumal for Vascular Biology and Medicine}

\section{RECEPTOR FOR ADVANCED GLYCATION END-PRODUCTS IS INVOLVED IN PLATELET HYPERACTIVATION AND ARTERIAL THROMBOSIS DURING CHRONIC KIDNEY DISEASE}

\begin{tabular}{|c|c|}
\hline Journal: & Thrombosis and Haemostasis \\
\hline Manuscript ID & TH-20-04-0207.R1 \\
\hline Manuscript Type: & Original Article: Cellular Haemostasis and Platelets \\
\hline Category: & Basic Science \\
\hline $\begin{array}{r}\text { Date Submitted by the } \\
\text { Author: }\end{array}$ & $\mathrm{n} / \mathrm{a}$ \\
\hline Complete List of Authors: & $\begin{array}{l}\text { Ortillon, Jérémy; UMR CNRS } 7369 \text { MEDyC } \\
\text { Hezard, Nathalie; AHP Marseille, Haematology Biology } \\
\text { Belmokhtar, Karim; UMR CNRS } 7369 \text { MEDyC } \\
\text { Kawecki, Charlotte; Inserm U1176 } \\
\text { Terryn, Christine; University of Reims, Plateforme Imagerie cellulaire et } \\
\text { tissulaire } \\
\text { Fritz, Günter; University of Freiburg, Institute of Neuropathology } \\
\text { Neurozentrum } \\
\text { KAUSKOT, Alexandre; INSERM U1176 } \\
\text { Schmidt, Ann Marie; New York University School of Medicine } \\
\text { Rieu, Philippe; CHU of Reims, Nephrology } \\
\text { Nguyen, Philippe; CHU Robert Debre, Laboratoire D'Hematologie } \\
\text { MAURICE, Pascal; UMR CNRS } 7369 \text { MEDyC, } \\
\text { Touré, Fatouma; CHU Limoges, Division of Nephrology }\end{array}$ \\
\hline Keywords: & $\begin{array}{l}\text { Chronic Kidney Disease, RAGE, Platelets, Arterial thrombosis, Uremic } \\
\text { toxins }\end{array}$ \\
\hline
\end{tabular}




\title{
RECEPTOR FOR ADVANCED GLYCATION END-PRODUCTS IS INVOLVED IN PLATELET HYPERACTIVATION AND ARTERIAL THROMBOSIS DURING CHRONIC KIDNEY DISEASE
}

\author{
Jérémy ORTILLON ${ }^{1}$, Nathalie HEZARD ${ }^{2}$, Karim BELMOKHTAR ${ }^{1}$, Charlotte KAWECKI ${ }^{1}$, \\ Christine TERRYN ${ }^{3}$, Guenter FRITZ ${ }^{4}$, Alexandre KAUSKOT ${ }^{5}$, Ann Marie SCHMIDT 6 , Philippe \\ RIEU ${ }^{1,7}$, Philippe NGUYEN 2 , Pascal MAURICE ${ }^{1}$ and Fatouma TOURÉ ${ }^{1,8}$
}

\section{What is known on this topic?}

- Chronic kidney disease (CKD) is associated with an increased frequency of thrombotic events and accumulation of uremic toxins.

- Some of these uremic toxins can interact with the Receptor for Advanced Glycation End products (RAGE).

\section{What does this paper add?}

- CKD induces platelet hyperactivation and accelerates arterial thrombus formation.

- RAGE deletion has a protective role in CKD-induced platelet hyperactivation and arterial thrombosis.

- RAGE ligands binding to RAGE are involved in CKD-induced platelet hyperactivation. 


\title{
RECEPTOR FOR ADVANCED GLYCATION END-PRODUCTS IS \\ INVOLVED IN PLATELET HYPERACTIVATION AND ARTERIAL \\ THROMBOSIS DURING CHRONIC KIDNEY DISEASE
}

\author{
Jérémy ORTILLON ${ }^{1}$, Nathalie HEZARD ${ }^{2}$, Karim BELMOKHTAR ${ }^{1}$, Charlotte KAWECKI ${ }^{1}$, \\ Christine TERRYN 3 , Guenter FRITZ ${ }^{4}$, Alexandre KAUSKOT 5 , Ann Marie SCHMIDT 6 , Philippe \\ RIEU ${ }^{1,7}$, Philippe NGUYEN 2 , Pascal MAURICE ${ }^{1}$ and Fatouma TOURÉ 1,8
}

${ }^{1}$ UMR CNRS 7369 Matrice Extracellulaire et Dynamique Cellulaire (MEDyC), Team 2 "Matrix Aging and Vascular Remodelling", Université de Reims Champagne Ardenne (URCA), Reims, France

${ }^{2}$ EA3801, Hémostase et Remodelage Vasculaire Post-Ischémique (HERVI), Faculté de Médecine \& CHU Reims, Hôpital Robert Debré, Laboratoire d'Hématologie, Reims, France

${ }^{3}$ PICT Platform, Université de Reims Champagne Ardenne (URCA), Reims, France

${ }^{4}$ University of Freiburg, Institute of Neuropathology Neurozentrum, Freiburg, Germany

5 INSERM U1176, Le Kremlin Bicêtre, Paris, France

${ }^{6}$ Diabetes Research Program, Division of Endocrinology, Diabetes and Metabolism, Department of Medicine, New York University School of Medicine, New York, USA

${ }^{7}$ CHU Reims, Division of Nephrology, Reims, France

${ }^{8}$ CHU Limoges, Division of Nephrology, Limoges, France

\section{Corresponding authors:}

- Dr Pascal Maurice (PhD), UMR CNRS/URCA 7369 MEDyC, URCA, UFR Sciences Exactes et Naturelles, Moulin de la Housse, BP1039, 51687 Reims cedex 2, France.

Phone: (+33) 326913275 ; e-mail: pascal.maurice@univ-reims.fr

- Dr Fatouma Touré (MD, PhD), CHU Limoges, Division of Nephrology, Limoges, France.

E-mail: fatouma.toure@chu-limoges.fr 


\section{What is known on this topic?}

- Chronic kidney disease (CKD) is associated with an increased frequency of thrombotic events and accumulation of uremic toxins.

- Some of these uremic toxins can interact with the Receptor for Advanced Glycation End products (RAGE).

\section{What does this paper add?}

- CKD induces platelet hyperactivation and accelerates arterial thrombus formation.

- RAGE deletion has a protective role in CKD-induced platelet hyperactivation and arterial thrombosis.

- RAGE ligands binding to RAGE are involved in CKD-induced platelet hyperactivation.

Keywords: Chronic Kidney Disease, RAGE, Platelets, Arterial thrombosis, Uremic toxins

Number of figures: 5

Number of tables: 3

Total word count: 4628

Supplementary material: 1 


\begin{abstract}
Background - Chronic kidney disease (CKD) is associated with a high cardiovascular mortality due to increased rates of vascular lesions and thrombotic events, as well as serum accumulation of uremic toxins. A subgroup of these toxins (AGEs and S100 proteins) can interact with the receptor for advanced glycation end-products (RAGE). Objective - In this study, we analyzed the impact of CKD on platelet function and arterial thrombosis, and the potential role of RAGE in this process. Materials and methods - Twelve weeks after induction of CKD in mice, platelet function and time to complete carotid artery occlusion were analyzed in four groups of animals (sham-operated, CKD, Apoe ${ }^{-/}$, and Apoe - $^{-/} /$Ager $^{-/-}$mice). Results - Analysis of platelet function from whole blood and platelet-rich plasma showed hyperactivation of platelets only in CKD Apoe $^{-/}$mice. There was no difference when experiments were done on washed platelets. However, pre-incubation of such platelets with AGEs or S100 proteins induced RAGE-mediated platelet hyperactivation. In vivo, CKD significantly reduced carotid occlusion times of Apoe-/mice $(9.2 \pm 1.1$ vs $11.1 \pm 0.6$ min for sham, $\mathrm{p}<0.01)$. In contrast, $\mathrm{CKD}$ had no effect on occlusion times in Apoe ${ }^{-/ /} /$Ager $^{/-}$mice. Moreover, carotid occlusion in Apoe ${ }^{-/-}$CKD mice occurred significantly faster than in Apoe $\mathrm{A}^{-/} / \mathrm{Ager}^{-/-}$CKD mice $(\mathrm{p}<0.0001)$. Conclusion - Our results show that CKD induces platelet hyperactivation, accelerates thrombus formation in a murine model of arterial thrombosis, and that RAGE deletion has a protective role. We propose that RAGE ligands binding to RAGE is involved in CKD-induced arterial thrombosis.
\end{abstract}




\section{INTRODUCTION}

Individuals with chronic kidney disease (CKD) have a 10- to 20-fold higher risk of death due to cardiovascular complications than the general population ${ }^{1,2}$. The risk of cardiovascular events increases steadily with declining glomerular filtration rate ${ }^{2}$. Underlying factors include accelerated atherosclerosis, increased arterial stiffness and pathological arterial thrombosis, with related increases in the risk of myocardial infarction and stroke ${ }^{3-6}$. Arterial thrombosis is one of the key features of uremic vasculopathy but the pathophysiology is not completely understood. Indeed, the modifications of the vascular wall cannot totally account for this increased risk of arterial thrombosis. In addition, platelet dysfunction has been described in CKD patients, including defects in adhesion, secretion of alpha granule content, arachidonic acid and prostaglandin metabolism, and calcium mobilization ${ }^{7}$. Furthermore, platelets from patients with CKD have been reported to be hyperreactive, with increased expression of P-selectin and $\alpha_{\text {IIb }} \beta_{3}$ integrin ${ }^{7}$. The uremic milieu may play a role in CKD-related platelet dysfunction.

Aside from increased cardiovascular risk, CKD is also characterized by the retention of various solutes that are normally excreted by the kidneys ${ }^{8}$. Those solutes have emerged as key factors in CKD-related cardiovascular disease and are collectively named uremic toxins ${ }^{9,10}$. Recent findings suggest that uremic toxins may play a role in CKD-related platelet hyperactivation and arterial thrombosis ${ }^{11,12}$. For instance, indoxyl sulfate, a typical uremic toxin derived from tryptophan, has been reported to enhance platelet response and arterial thrombosis in uremic mice

11. Similarly, carbamylated low-density lipoproteins (cLDL), resulting from post-translational modification of LDL by carbamylation, is particularly increased in uremic conditions. Intravenous injection of cLDL in animal models accelerated platelet aggregation and arterial thrombus formation ${ }^{12}$. Among the uremic toxins, Advanced Glycation End products (AGEs) are 
long-lived heterogeneous protein adducts produced from a non-enzymatic chemical reaction between sugars and the amino groups of proteins (Maillard reaction) ${ }^{13}$. AGEs are of particular interest because they have established cardiovascular toxicity and are binding partners for the Receptor for Advanced Glycation End products (RAGE) ${ }^{14,15}$. RAGE is a multiligand, cell surface receptor of the immunoglobulin superfamily involved in various processes, such as cell migration, adhesion, and proliferation ${ }^{15-18}$. Other RAGE ligands are also elevated in CKD, such as S100 family proteins and serum amyloid A (SAA) ${ }^{19,20}$. RAGE engagement by its ligands initiates a pro-inflammatory response ${ }^{14,21,22}$, and RAGE signaling is also involved in uremiainduced atherosclerosis and atherosclerotic plaque vulnerability ${ }^{23}$. We and others have previously reported that RAGE is a key player in CKD-related atherosclerosis and vascular calcification $19,20,24,25$. However, the role of RAGE in platelet behavior and arterial thrombus formation has not been widely explored. Here, we used ex vivo and in vivo approaches to investigate the role of CKD and RAGE in modulating platelet function and the formation of arterial thrombus. 


\title{
METHODS
}

\section{Reagents and antibodies}

Horm collagen was purchased from Nycomed. ADP was obtained as Multiplate reagents from Roche Diagnostics. Rhodamine 6G, apyrase, prostaglandin $\mathrm{E}_{1}\left(\mathrm{PGE}_{1}\right)$, ferric chloride $\left(\mathrm{FeCl}_{3}\right)$, and thrombin were obtained from Sigma. D-Phe-Pro-Arg chloromethyl ketone dihydrochloride (PPACK) was obtained from Calbiochem. PE-coupled anti-mouse activated GPIIb/IIIa (clone JON/A), GPIb ${ }_{\alpha}$ (clone Xia.B2), and CD62P (clone Wug.E9) antibodies, and FITC-coupled anti-

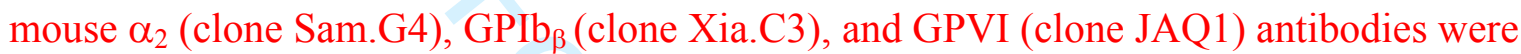
obtained from Emfret Analytics. PE-coupled anti-CD36 (clone CRF D-2712) and FITC-coupled anti- $\alpha_{\text {IIb }}$ (clone MWReg30) antibodies were obtained from BD Biosciences. Glycated-human serum albumin (HSA) and non-glycated-HSA were produced as previously described ${ }^{26}$.

\author{
Animals \\ Apolipoprotein E knockout (Apoe ${ }^{-/}$) mice on a C57BL/6 background were purchased from \\ Charles River Laboratories. Apoe-/-/Ager-/- (RAGE knockout) mice were generated using a \\ backcross-intercross scheme in the animal facility of New York University (Prof AM \\ Schmidt) ${ }^{19,24,27}$. Embryos from the F3 generation were rederived and mice arising from the \\ rederivation process transferred to the animal facility of Reims France (IFR53 Pôle Santé, Reims, \\ France). Animals were housed in a barrier- and pathogen-free animal facility with a 12-h light- \\ dark cycle and fed a regular chow diet. All experiments were approved by the ethics committee \\ for the use and care of animals of Reims Champagne Ardenne (CEEA-RCA-56).
}

\section{Induction of uremia}




\begin{abstract}
Twelve-week-old Apoe or Apoe $^{-/ /}$Ager $^{-/-}$mice were randomly assigned to CKD or shamoperated groups (Sham). A two-step surgical procedure was used to induce CKD ${ }^{19}$. Surgery was performed under isoflurane (Axience). The two poles of the left kidney were excised, and one week later the right kidney was removed, resulting in a $75 \%$ reduction of total renal mass. Control animals underwent sham operations involving decapsulation of both kidneys. All mice were sacrificed 12 weeks after surgery. All surgeries were done by the same operator blinded to the genotype of the mice.
\end{abstract}

\title{
Biochemical and hematological analysis
}

The serum concentration of urea, total cholesterol, triglycerides, calcium, and phosphorus were measured by automated assays using a Modular ${ }^{\circledR}$ analyzer (Roche Diagnostics). Complete blood counts, hematocrit, and hemoglobin were determined with a hematology cell counter ADVIA 2120 (Siemens).

\section{Whole blood platelet aggregation}

Mice were anesthetized with 25\% urethane (Sigma). Whole blood was collected from the inferior vena cava in $0.129 \mathrm{M}$ sodium citrate $(1 / 6, \mathrm{v} / \mathrm{v})$. Whole blood aggregation was monitored by impedance aggregometry at $37^{\circ} \mathrm{C}$ under stirring using the Multiplate analyzer ${ }^{\circledR}$. Whole blood was diluted in physiological saline (1:1) and platelet aggregation was induced by adding Horm collagen $(2.5 \mu \mathrm{g} / \mathrm{mL})$, ADP $(5 \mu \mathrm{M})$ or thrombin $(10 \mathrm{mU} / \mathrm{mL})$. Curves were recorded for 6 min and platelet aggregation was determined as the area under the curve (AUC) in arbitrary units $\left(\mathrm{AU}{ }^{*} \min \right)$ 


\section{Platelet-rich plasma aggregation}

Blood was collected from mice as described above. Whole blood $(700 \mu \mathrm{L})$ was mixed with Tyrode buffer $(500 \mu \mathrm{L})$. Diluted platelet-rich plasma (PRP) was separated by centrifugation at $100 \mathrm{x} g$ for $10 \mathrm{~min}$ at $22^{\circ} \mathrm{C}$. Diluted platelet-poor plasma (PPP) was prepared by further centrifugation at $800 \mathrm{x} g$ for $2 \mathrm{~min}$. Platelets were counted and adjusted to $2.10^{8} / \mathrm{mL}$. Platelet aggregation was monitored by measuring light transmission through the stirred suspension of diluted PRP at $37^{\circ} \mathrm{C}$ with a Soderel ${ }^{\circledR}$ aggregometer. Thrombin was used as platelet agonist for homogeneity with whole blood and washed platelet aggregation experiments. Aggregations were triggered by 50 and $100 \mathrm{mU} / \mathrm{mL}$ thrombin since low concentrations of thrombin $(<10 \mathrm{mU} / \mathrm{mL})$ were without effect.

\section{Washed platelet aggregation}

Mouse platelets were prepared as described previously ${ }^{28}$. Using this protocol, platelet suspensions were estimated to be more than $99 \%$ pure $^{28}$. Briefly, whole blood was collected from the inferior vena cava and mixed with $80 \mu \mathrm{M}$ PPACK and 10\% (v/v) ACD-C buffer (124 mM sodium citrate, $130 \mathrm{mM}$ citric acid, $110 \mathrm{mM}$ dextrose, $\mathrm{pH}$ 6.5). PRP was obtained by centrifuging whole blood for $7 \mathrm{~min}$ at $160 \mathrm{x}$ g. Platelets were obtained from PRP after centrifugation for $10 \mathrm{~min}$ at $670 \mathrm{xg}$ and washed in the presence of apyrase $(100 \mathrm{mU} / \mathrm{mL})$ and $\mathrm{PGE}_{1}(1 \mu \mathrm{M})$ to minimize platelet activation. The number of platelets was adjusted to $2.10^{8} / \mathrm{mL}$ in modified Tyrode-HEPES buffer $\left(137 \mathrm{mM} \mathrm{NaCl}, 2 \mathrm{mM} \mathrm{KCl}, 0.3 \mathrm{mM} \mathrm{NaH}_{2} \mathrm{PO}_{4}, 5.5 \mathrm{mM}\right.$ glucose, 5 mM N-2-hydroxyethylpiperazine-N'-2-ethanesulfonic acid, $12 \mathrm{mM} \mathrm{NaHCO}, 2 \mathrm{mM}$ $\mathrm{CaCl}_{2}, \mathrm{pH}$ 7.3). Platelet aggregations in response to thrombin were measured with a Soderel ${ }^{\circledR}$ aggregometer. To evaluate RAGE involvement in washed platelet aggregation, HSA was used to 
produce glycated albumin, enriched in carboxymethyllysine (CML), a well-characterized RAGE ligand. Briefly, $0.5 \mathrm{~g}$ of HSA were dissolved in $10 \mathrm{~mL}$ of $0.5 \mathrm{M}$ sodium phosphate buffer $(\mathrm{pH}$ 7.4) containing $0.05 \% \mathrm{NaN}_{3}$ and $3 \mathrm{~g}$ of D-glucose. Non-glycated albumin was prepared similarly, except that glucose was omitted, and used as control. The solution was sterilized by ultrafiltration $(0.45 \mu \mathrm{m}$ filter $)$ and incubated at $37^{\circ} \mathrm{C}$ for 90 days. The samples were then dialyzed against PBS 26.

\title{
Flow cytometry
}

Activated GPIIb/IIIa (JON/A) and CD62P (P-selectin) were used as markers of platelet activation and secretion, respectively. Platelet surface expression of selected markers was also evaluated such as $\mathrm{GPIb}_{\alpha}, \mathrm{GPIb}_{\beta}$, GPIV (also known as CD36), GPVI, and integrin $\alpha_{2}$ and $\alpha_{\mathrm{IIb}}$ chains. Diluted whole blood or washed platelets $\left(2.10^{6} / \mathrm{mL}\right)$ were stimulated with a range of agonists, as indicated. After incubation for $5 \mathrm{~min}$ at room temperature without stirring, whole blood or washed platelets were incubated with appropriate fluorophore-conjugated antibodies for $10 \mathrm{~min}$ at room temperature. The reaction was stopped by adding $500 \mu \mathrm{L}$ of PBS, and immediately analyzed with a FC500 flow cytometer (Beckman Coulter). The platelet population was gated using their forward and side scatter characteristics. Acquisition and processing data from 10,000 platelets were collected and analyzed using CXP software (Coulter). The Mean fluorescence intensity (MFI) of the whole platelet population was used.

\author{
Carboxymethyllysine quantification by Liquid Chromatography-MS/MS \\ For plasma AGE measurements, CML was measured in plasma samples using mass spectrometry \\ coupled with liquid chromatography (LC-MS/MS). Total AGEs (free adducts and protein-linked)
}




\section{Mouse model of carotid artery thrombosis}

Mice were anesthetized with $25 \%$ urethane. Rhodamine $6 \mathrm{G}(4 \mathrm{mg} / \mathrm{kg})$ was used to label endogenous platelets and leukocytes. The carotid artery was isolated from surrounding tissue by a black plastic sheet. Vascular injury was performed by applying a piece of filter paper $(2 \times 1 \mathrm{~mm}$, $1 \mathrm{~mm}$ thick) saturated with $7.5 \% \mathrm{FeCl}_{3}$ onto the carotid artery for $1 \mathrm{~min}$. After removing the filter paper, thrombus formation was monitored in real time with an epifluorescent microscope (Nikkon Eclipse E400) connected to a digital camera. Time to complete occlusion was defined as the arrest of blood flow for at least $1 \mathrm{~min}^{30}$.

\section{Statistical analysis}

Results are expressed as the mean \pm SEM. Statistical analysis was performed using GraphPad 
Prism software 7.0. Groups were compared using a two-tailed Mann-Whitney test. $P$ values of less than 0.05 were considered statistically significant. 


\section{RESULTS}

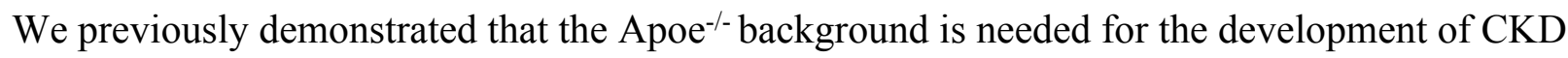
induced vasculopathy ${ }^{19,27}$. Therefore, this well-established uremic mouse model was used in this study to evaluate the role of CKD and RAGE in platelet aggregation and arterial thrombosis. $\mathrm{Apoe}^{-/-}$and $\mathrm{Apoe}^{-/ /} / \mathrm{Ager}^{-/-}$mice were subjected to a sham operation (sham) or surgically-induced chronic kidney disease (CKD). Twelve weeks after surgery, CKD induction in both genotypes was associated with significantly higher urea, creatinine, and cholesterol levels. Triglyceride, calcium, and phosphorus levels were unmodified. As expected, the number of red blood cells, hemoglobin level and hematocrit were significantly lower in the uremic versus sham-operated group (Table 1).

\section{Uremia induces platelet hyperactivation}

We first investigated the effect of CKD-induced uremia on platelet activation in whole blood by measuring platelet $\alpha_{\mathrm{II}} \beta_{3}$ activation using the monoclonal antibody JON/A specific for the activated conformation of the mouse integrin, and P-selectin surface expression, by flow cytometry. At resting state and relative to Apoe ${ }^{-/-}$sham mice, CKD had no effect on the activation level of $\alpha_{\mathrm{IIb}} \beta_{3}$ and P-selectin surface expression (Fig. 1A). Platelet activation by low thrombin concentration $(10 \mathrm{mU} / \mathrm{mL})$ led to significantly higher expression of activated $\alpha_{\mathrm{IIb}} \beta_{3}(\mathrm{MFI}$, $3.1 \pm 0.6$ vs $1.9 \pm 0.5 ; p<0.05)$ and P-selectin (MFI, $7.0 \pm 1.4$ vs $3.4 \pm 0.7 ; p<0.05$ ) in whole blood from CKD than sham mice (Fig. 1A). We next assessed the effect of CKD on whole blood platelet aggregation induced by two different agonists, ADP and collagen. As shown in Fig. 1B, CKD-induced uremia significantly increased whole blood platelet aggregation by 2.6 -fold $(p<0.01)$ in response to $5 \mu \mathrm{M}$ ADP and 1.7 -fold $(p<0.01)$ in response to $2.5 \mu \mathrm{g} / \mathrm{mL}$ collagen 
compared to Apoe ${ }^{-/-}$sham animals. Of note, a second wave of aggregation was systematically observed in the CKD condition during ADP-induced platelet aggregation, indicative of dense granule secretion. The effect of CKD on thrombin-induced platelet aggregation in PRP was also evaluated (Fig. 1C). Again, platelet aggregation was significantly higher in the CKD condition in response to both low $(50 \mathrm{mU} / \mathrm{mL})$ and high $(100 \mathrm{mU} / \mathrm{mL})$ thrombin concentrations. Platelet aggregation induced by low doses of thrombin was not sustained and reversible, and aggregation percentages were $41 \pm 7 \%$ for the CKD group $v s 21 \pm 6 \%$ for the Apoe ${ }^{-/-}$sham group $(p<0.05)$. In contrast, platelet aggregation induced by high doses of thrombin was stable and sustained, and the aggregation reached $82 \pm 3 \%$ for the CKD group vs $62 \pm 6 \%$ for the Apoe ${ }^{-/-}$sham group $(p<0.01)$. Overall, these data show that CKD-induced uremia affects platelet function by increasing both platelet activation and aggregation in whole blood and PRP.

\section{Deletion of RAGE limits uremia-induced platelet hyperactivation}

The effects of RAGE deletion on both platelet activation and aggregation parameters were evaluated in whole blood and PRP. As shown in Fig. 1A, activation of $\alpha_{\mathrm{IIb}} \beta_{3}$ and P-selectin surface exposure were similar between the Apoe A $^{-/ /}$Ager $^{-/-}$CKD and Apoe A $^{-/ /} /$Ager $^{-/-}$sham-operated groups, both in the basal state and after stimulation with low doses of thrombin $(10 \mathrm{mU} / \mathrm{mL})$. However, stimulation with higher doses of thrombin $(50 \mathrm{mU} / \mathrm{mL})$ induces platelet hyperactivation in Apoe - $^{-/}$Ager $^{-/-}$CKD compared to Apoe cher $^{-/-}$Sham mice (supplementary Fig. S1). Platelet aggregation in whole blood was significantly higher in the CKD group than in the sham-operated group in response to $5 \mu \mathrm{M}$ ADP (575 \pm 80 vs $97 \pm 46 \mathrm{AU} *$ min; $p<0.01)$ and 2.5 $\mu \mathrm{g} / \mathrm{mL}$ collagen $(571 \pm 61$ vs $241 \pm 72 \mathrm{AU} * \min ; p<0.01)$ (Fig. 1B). Again, a second wave of aggregation was systematically observed in the CKD group during ADP-induced platelet 
aggregation. Using PRP, we observed that CKD did not further increase aggregation of Apoe-//Ager-/ platelets in response to low doses $(50 \mathrm{mU} / \mathrm{mL})$ of thrombin compared to the shamoperated group (Fig. 1C), whereas CKD increased platelet aggregation at the higher concentration of thrombin $(100 \mathrm{mU} / \mathrm{mL})(70 \pm 1$ vs $50 \pm 4 \%$; $p<0.01)$ (Fig. 1C). Interestingly, a spontaneous disaggregation occurring after 5 minutes was observed in the Apoe $\mathrm{e}^{-/ /} / \mathrm{Ager}^{-/}$shamoperated group (62.5\% of cases, Table 2$)$. When comparing thrombin-induced $\alpha_{\mathrm{II}} \beta_{3}$ activation and P-selectin cell surface expression between the Apoe $\mathrm{e}^{-/ /} \mathrm{Ager}^{-/ /}$and the Apoe ${ }^{-/}$groups for the CKD condition, RAGE deletion led to significantly lower values $(55 \%, p=0.05$, and $80 \%$, $p<0.05$, lower, respectively) (Fig. 1A). There was no difference between the two groups under sham condition.

We next performed flow cytometry analysis and measured platelet expression levels of GPIb $\mathrm{Ib}_{\alpha}$ GPIb $_{\beta}$, CD36 (GPIV), GPVI, $\alpha_{2}$ and $\alpha_{\mathrm{IIb}} \beta_{3}$ for both genotypes (Apoe ${ }^{-/-}$and Apoe $\mathrm{Ap}^{-/ /} \mathrm{Ager}^{-/}$). Platelet surface expression of these receptors was comparable between both genotypes and CKDinduced uremia had no effect (Fig. 2). In addition, the number of circulating platelets and mean platelet volume were comparable (Table 3). Taken together these observations suggest that RAGE deletion decreases the effects of CKD on platelet activation and that RAGE participates in CKD-induced platelet hyperactivation.

\section{Effect of CKD and RAGE deletion on washed platelet function}

We further investigated whether CKD-induced uremia and/or RAGE directly affect platelet function by evaluating the impact of uremia and RAGE deletion on washed platelet activation and aggregation. Washed platelet aggregation induced by various concentrations of thrombin (Fig. 3A), as well as the levels of $\alpha_{\mathrm{II}} \beta_{3}$ activation (Fig. 3B) and P-selectin cell surface expression 
(Fig. 3C), were similar for both genotypes. Moreover, there was no observable difference between the CKD and sham conditions. Overall, these data show that the effects of CKD and RAGE on platelet function are abolished when platelets are isolated from their plasma environment.

\section{RAGE ligands accumulate in the uremic serum and are involved in platelet hyperactivation} Because our results suggested that the uremic milieu is a critical component of CKD-mediated platelet hyperactivation, we next analyzed the serum concentration of carboxymethyllysine (CML), known to be associated with $\mathrm{CKD}^{31}$, in $\mathrm{Apoe}^{-/-}$sham and CKD mice. Indeed, uremia is associated with the retention of various solutes that are normally excreted by the kidneys, including potential binding partners for RAGE, such as AGEs and S100 proteins. As shown in Fig. 4A, CML concentration was significantly higher in the serum of CKD than sham mice $(0.26$ \pm 0.02 vs $0.20 \pm 0.01 \mathrm{mmol} / \mathrm{mol}$ lysine, respectively; $p<0.01)$. In contrast, the concentration of CML in Apoe-//Ager-/- CKD sera was numerically, albeit non-significantly higher than that in Apoe $^{-/-} /$Ager $^{-/-}$sham sera, $(0.21 \pm 0.02$ versus $0.18 \pm 0.01 \mathrm{mmol} / \mathrm{mol}$ lysine, respectively; $p=$ 0.06). There was no observable difference between the two genotypes for the sham condition. To definitively demonstrate that RAGE ligands may directly modulate platelet function, we evaluated the effects of ex vivo incubation of two different AGEs on washed Apoe ${ }^{-/-}$and Apoe Ap $^{-/}$ /Ager-/- platelet aggregation, using glycated-HSA and S100A12, a typical calcium-binding protein belonging to the $\mathrm{S} 100$ protein family ${ }^{32}$. Incubation of washed platelets with glycatedHSA or S100A12 did not induce platelet activation or aggregation (data not shown). However, pre-incubation of washed Apoe ${ }^{-/-}$platelets with glycated-HSA $(100 \mu \mathrm{g} / \mathrm{mL})$ for 10 minutes before stimulation by thrombin $(25 \mathrm{mU} / \mathrm{mL})$ led to a significant, 2.5 -fold increase in aggregation relative 
to pre-incubation with non-glycated-HSA $(p=0.028)$ (Fig. 4B). Similar effects were observed with S100A12 (Fig. 4C). Increasing the concentration of S100A12 led to potentiation of washed platelet aggregation in response to thrombin. For instance, at $60 \mu \mathrm{g} / \mathrm{mL} \mathrm{S100A12,} \mathrm{platelet}$ aggregation was 1.7-fold higher than the control. These potentiating effects of glycated-HSA and S100A12 were abolished in washed Apoe - $^{-/}$Ager $^{-/}$platelets (Fig. 4B, 4C). Overall, these results strongly suggest that the potentiating effects of glycated-HSA and S100A12 on washed platelet aggregation induced by thrombin involve RAGE.

\section{Uremia accelerates arterial thrombosis in vivo and RAGE deletion is protective}

We finally explored the impact of CKD-induced uremia and RAGE on in vivo thrombosis using the $\mathrm{FeCl}_{3}$-induced carotid thrombosis model ${ }^{30}$. Mice were injected with Rhodamine $6 \mathrm{G}$ and thrombus development and complete vessel occlusion were monitored in real time, under a microscope, after application of a patch containing $7.5 \% \mathrm{FeCl}_{3}$. Time to complete arterial occlusion was significantly shorter in Apoe $^{-/-}$CKD than Apoe ${ }^{-/-}$sham mice $(9.2 \pm 1.1$ vs $11.1 \pm 1.2$ min; $p<0.01$; Fig. 5A, 5B). Deletion of RAGE (Apoe (-//Ager $^{-/-}$sham) significantly delayed occlusion times $(13.1 \pm 1.5 \mathrm{~min})$ relative to $\mathrm{Apoe}^{-/-}$sham mice, and induction of CKD in these

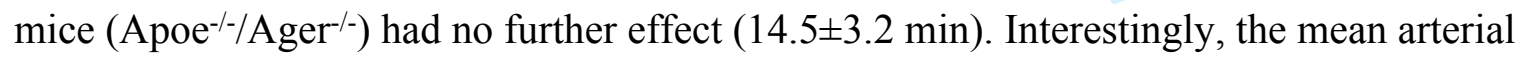
occlusion time of Apoe $\mathrm{Ager}^{-/ /}$- CKD mice was longer than that of Apoe ${ }^{-/-}$CKD mice (14.6 \pm 3.2 $\min v s 9.2 \pm 1.1 \mathrm{~min} ; p<0.0001)$. In addition, the percentage of carotid arteries showing embolization before complete occlusion was 6.5 times higher in Apoe Aper $^{-/ /}$CKD than Apoe Ag- $^{-/}$ CKD mice (54.5\% vs 8.3\%; Fig. 5C). These observations strongly suggest that CKD-induced uremia accelerates arterial thrombus formation and that RAGE is involved in this phenomenon. 


\section{DISCUSSION}

Individuals with CKD have a much higher risk of death due to cardiovascular complications than the general population ${ }^{2,5}$. Vascular disease in these patients is characterized by accelerated vascular ageing, including vascular calcification affecting the medial layer of vessels, and extensive atherosclerosis ${ }^{4,5,33}$. This vascular disease is also associated with thrombotic events ${ }^{2}$. The underlying mechanisms involved in arterial thrombosis are not fully understood and therefore constitute a critical barrier for providing therapy. Recently, we and others reported that the pro-inflammatory receptor RAGE is involved in specific CKD-related vascular changes, such as uremic atherosclerosis and uremic vascular calcification ${ }^{19,20,25,34}$. Indeed, CKD is considered to be a condition associated with increased activation of RAGE. Various solutes that are normally excreted by the kidneys accumulate in the sera with declining kidney function. Among them, AGEs and other RAGE ligands, such as S100 family proteins, accumulate during CKD, leading to increased engagement of this pro-inflammatory receptor and subsequent vascular remodeling 8 , 35 .

Here, we investigated the impact of CKD on platelet function and arterial thrombus formation, and the involvement of RAGE in this phenomenon. We report that uremia induces platelet hyperactivation and accelerates arterial thrombus formation in a murine model of arterial thrombosis ${ }^{30}$. We show that RAGE-ligand accumulation and RAGE engagement during CKD is involved in arterial thrombus formation, at least partially through increased platelet activation. We analyzed platelet activation markers and platelet aggregation in whole blood and PRP. Both methods showed increased platelet aggregation in the CKD condition. This platelet hyperactivation was associated with increased $\alpha_{\mathrm{IIb}} \beta_{3}$ activation and P-selectin exposure. Importantly, RAGE deletion inhibited CKD effects when low doses of agonists were used. 
Furthermore, platelet aggregation was less stable when RAGE was deleted. This suggests that 1) in CKD, RAGE modulates platelet sensitivity in the presence of small doses of agonists but this mechanism is overridden in the presence of higher doses of agonists, and 2) RAGE deletion is sufficient to inhibit the effects of CKD. In addition, isolation of platelets of either genotype from their plasma environment abolished this hyperactivation associated with CKD condition, suggesting that platelets are not intrinsically modified by CKD or RAGE deletion, but rather a priming effect of the uremic environment. We further explored this hypothesis using RAGE ligands and demonstrated that pre-incubating platelets isolated from Apoe ${ }^{-/-}$mice with RAGE ligands, such as AGEs (Glycated-BSA) or S100 proteins, induced increased platelet aggregation in response to low dose of thrombin. Moreover, deletion of RAGE prevented these effects, suggesting that this receptor is a central player in the modulatory effect in response to AGEs and S100. These data are consistent with recent studies showing that platelet aggregation in response to weak agonists, such as serotonin and ADP, increases in response to AGEs ${ }^{36-38}$. For instance, Gawlowski et al. reported increased platelet aggregation after stimulation with food-derived AGE or AGE isolated from human sera ${ }^{36}$. This platelet hyperactivation was associated with CD62, CD63, and RAGE overexpression on the platelet surface. Similarly, Herczenik et al. reported a pro-aggregatory effect on platelets exposed to modified proteins with amyloid properties ${ }^{37}$. They further established a potential link with RAGE using sRAGE to inhibit the interaction of amyloid proteins with RAGE. RAGE-mediated activation of platelets was also suggested by Ahrens et al. 39. They reported an interaction of RAGE with HMGB1 (high mobility group box 1), involved in platelet activation and the atherosclerosis process. In the present study, we did not analyze the role of HMGB1. However, HMGB1 serum levels have been reported to be significantly increased in CKD patients and negatively correlated with eGFR, and positively correlated with 
markers of inflammation and nutrition ${ }^{40}$. Hence, our results are in agreement with these previous reports.

Our study highlights a new role for RAGE in the modulation of platelet function and arterial thrombosis during CKD. We found that the induction of uremia in Apoe-/- mice accelerates arterial thrombosis formation in vivo. This is the first report on a specific prothrombotic effect of CKD in vivo in a mouse model of carotid-artery thrombosis. Here, we addressed the question of arterial thrombosis and focused our experiments on platelet activation and aggregation. However, platelet hyperactivation may also increase thrombogenicity in venous conditions. For instance, overexpression of P-selectin may have an impact on neutrophil and monocyte adhesion and activation which play a major part in venous thrombogenicity ${ }^{41}$. Therefore, further investigation is needed to test the relevance of our results on venous thrombogenicity. Moreover, we focused on a specific subclass of uremic toxins. However, our results strengthen recent findings by Holy et al. showing the prothrombotic effect of another uremic by-product, the carbamylated low density lipoprotein (cLDL) ${ }^{12}$, in a murine model of arterial thrombosis after carotid photochemical injury. Overall, their results suggest that the post-translational modification of proteins can induce platelet hyperaggregability, leading to arterial thrombosis. Indeed, protein carbamylation is highly elevated in CKD and considered as a hallmark of uremia. Taken together, these results suggest a critical role of the uremic milieu on platelet hyperactivation promoting arterial thrombosis. These findings are consistent with previous publications from CKD patients reporting the propensity of the uremic milieu to induce thrombosis. For instance, in the context of percutaneous coronary intervention, one-year mortality related to stent thrombosis is higher in CKD patients (15.2\%) and those on dialysis (10.0\%) than in non-CKD patients $(1.9 \%)^{42,43}$. A potential explanation has been put forward by Chitalia et al. ${ }^{44}$, who reported the modulation of cell function by uremic serum. They showed increased expression of tissue factor during the 
incubation of primary cultures of human vascular smooth muscle cells with uremic serum and isolated uremic toxins, such as indole-3-acetic acid. Overall, these results suggest a prothrombotic state in some patients, related to CKD and mediated by the uremic milieu. Another example comes from Jain et al. who reported greater response to ADP in platelets from CKD patients compared to platelets from matched controls ${ }^{45}$. Furthermore, they reported higher residual platelet responsiveness in clopidrogel-treated CKD patients than control patients, again demonstrating that the uremic milieu is able to increase platelet activation and aggregation. In summary, we report a novel mechanism by which RAGE ligand accumulation, due to uremia, increases RAGE-dependent platelet hyperactivation. This may contribute to creating a prothrombotic state in which circulating CKD platelets are primed for activation, leading to enhanced thrombus formation. These results constitute a reasonable basis for designing preclinical studies aiming at targeting the RAGE/ RAGE-ligand axis as a promising approach to preventing thrombotic complications associated with CKD. 


\section{ACKNOWLEDGEMENTS}

The authors would like to thank Ms. Valerie Creuza for her appreciated technical assistance in this study and Ms. Leslie Migeon for secretarial assistance in finalizing the manuscript.

\section{FUNDING}

This work was supported by funding from CNRS, URCA. FT was recipient of a grant from the Société Francophone de Nephrologie Dialyse Transplantation (SFNDT). CK was recipient of a scholarship from the Nouvelle Société Francophone d'Athérosclérose (NSFA).

\section{DISCLOSURE}

The authors have no conflict of interest to disclose.

\section{CONTRIBUTIONS}

FT, PM NH, PN and JO designed the experiments. JO and KB realized the surgery of mouse CKD model. JO and CK realized the animal model of arterial thrombosis. JO and NH worked together for analysis of platelet functions ex-vivo. CT provided help and material for monitoring arterial thrombosis in vivo. AK and PR participate to scientific discussions. JO and FT wrote the first draft of the manuscript. FT, PM, and PN wrote the final version of the manuscript. 


\section{REFERENCES}

1. Parfrey PS and Foley RN. The clinical epidemiology of cardiac disease in chronic renal failure. J Am Soc Nephrol. 1999;10:1606-15.

2. Go AS, Chertow GM, Fan D, McCulloch CE and Hsu CY. Chronic kidney disease and the risks of death, cardiovascular events, and hospitalization. N Engl J Med. 2004;351:1296-305.

3. Vanholder R, Massy Z, Argiles A, Spasovski G, Verbeke F, Lameire N and European Uremic Toxin Work G. Chronic kidney disease as cause of cardiovascular morbidity and mortality. Nephrol Dial Transplant. 2005;20:1048-56.

4. Drueke TB and Massy ZA. Atherosclerosis in CKD: differences from the general population. Nat Rev Nephrol. 2010;6:723-35.

5. Fort J. Chronic renal failure: a cardiovascular risk factor. Kidney Int Suppl. 2005:S25-9.

6. London GM, Marchais SJ, Guerin AP and Metivier F. Arteriosclerosis, vascular calcifications and cardiovascular disease in uremia. Curr Opin Nephrol Hypertens. 2005;14:52531.

7. Landray MJ, Wheeler DC, Lip GY, Newman DJ, Blann AD, McGlynn FJ, Ball S, Townend $\mathrm{JN}$ and Baigent $\mathrm{C}$. Inflammation, endothelial dysfunction, and platelet activation in patients with chronic kidney disease: the chronic renal impairment in Birmingham (CRIB) study. Am J Kidney Dis. 2004;43:244-53.

8. Vanholder R, De Smet R, Glorieux G, Argiles A, Baurmeister U, Brunet P, Clark W, Cohen G, De Deyn PP, Deppisch R, Descamps-Latscha B, Henle T, Jorres A, Lemke HD, Massy ZA, Passlick-Deetjen J, Rodriguez M, Stegmayr B, Stenvinkel P, Tetta C, Wanner C, Zidek W and European Uremic Toxin Work G. Review on uremic toxins: classification, concentration, and interindividual variability. Kidney Int. 2003;63:1934-43. 
9. Brunet P, Gondouin B, Duval-Sabatier A, Dou L, Cerini C, Dignat-George F, JourdeChiche N, Argiles A and Burtey S. Does uremia cause vascular dysfunction? Kidney Blood Press Res. 2011;34:284-90.

10. Jourde-Chiche N, Dou L, Cerini C, Dignat-George F and Brunet P. Vascular incompetence in dialysis patients--protein-bound uremic toxins and endothelial dysfunction. Semin Dial. 2011;24:327-37.

11. Karbowska M, Kaminski TW, Znorko B, Domaniewski T, Misztal T, Rusak T, Pryczynicz A, Guzinska-Ustymowicz K, Pawlak K and Pawlak D. Indoxyl Sulfate Promotes Arterial Thrombosis in Rat Model via Increased Levels of Complex TF/VII, PAI-1, Platelet Activation as Well as Decreased Contents of SIRT1 and SIRT3. Front Physiol. 2018;9:1623. 12. Holy EW, Akhmedov A, Speer T, Camici GG, Zewinger S, Bonetti N, Beer JH, Luscher TF and Tanner FC. Carbamylated Low-Density Lipoproteins Induce a Prothrombotic State Via LOX-1: Impact on Arterial Thrombus Formation In Vivo. J Am Coll Cardiol. 2016;68:16641676.

13. Maillard LC. Action des acides aminés sur les sucres ; formation des mélanoïdes par voie méthodiques. 1912;154:66-68.

14. Schmidt AM, Hori O, Chen JX, Li JF, Crandall J, Zhang J, Cao R, Yan SD, Brett J and Stern D. Advanced glycation endproducts interacting with their endothelial receptor induce expression of vascular cell adhesion molecule-1 (VCAM-1) in cultured human endothelial cells and in mice. A potential mechanism for the accelerated vasculopathy of diabetes. J Clin Invest. $1995 ; 96: 1395-403$.

15. Schmidt AM, Yan SD, Yan SF and Stern DM. The multiligand receptor RAGE as a progression factor amplifying immune and inflammatory responses. J Clin Invest. 2001;108:94955. 
16. Koch M, Chitayat S, Dattilo BM, Schiefner A, Diez J, Chazin WJ and Fritz G. Structural basis for ligand recognition and activation of RAGE. Structure. 2010;18:1342-52.

17. Goury A, Meghraoui-Kheddar A, Belmokhtar K, Vuiblet V, Ortillon J, Jaisson S, Devy J, Le Naour R, Tabary T, Cohen JH, Schmidt AM, Rieu P and Toure F. Deletion of receptor for advanced glycation end products exacerbates lymphoproliferative syndrome and lupus nephritis in B6-MRL Fas 1pr/j mice. J Immunol. 2015;194:3612-22.

18. Rai V, Toure F, Chitayat S, Pei R, Song F, Li Q, Zhang J, Rosario R, Ramasamy R, Chazin WJ and Schmidt AM. Lysophosphatidic acid targets vascular and oncogenic pathways via RAGE signaling. J Exp Med. 2012;209:2339-50.

19. Belmokhtar K, Robert T, Ortillon J, Braconnier A, Vuiblet V, Boulagnon-Rombi C, Diebold MD, Pietrement C, Schmidt AM, Rieu P and Toure F. Signaling of Serum Amyloid A Through Receptor for Advanced Glycation End Products as a Possible Mechanism for UremiaRelated Atherosclerosis. Arterioscler Thromb Vasc Biol. 2016;36:800-9.

20. Gawdzik J, Mathew L, Kim G, Puri TS and Hofmann Bowman MA. Vascular remodeling and arterial calcification are directly mediated by S100A12 (EN-RAGE) in chronic kidney disease. Am J Nephrol. 33:250-9.

21. $\mathrm{Xu} \mathrm{B,} \mathrm{Chibber} \mathrm{R,} \mathrm{Ruggiero} \mathrm{D,} \mathrm{Kohner} \mathrm{E,} \mathrm{Ritter} \mathrm{J} \mathrm{and} \mathrm{Ferro} \mathrm{A.} \mathrm{Impairment} \mathrm{of} \mathrm{vascular}$ endothelial nitric oxide synthase activity by advanced glycation end products. FASEB J. $2003 ; 17: 1289-91$.

22. Toure F, Fritz G, Li Q, Rai V, Daffu G, Zou YS, Rosario R, Ramasamy R, Alberts AS, Yan SF and Schmidt AM. Formin mDia1 mediates vascular remodeling via integration of oxidative and signal transduction pathways. Circ Res. 2012 110:1279-93. 


\section{Zhao D, Tong L, Zhang L, Li H, Wan Y and Zhang T. Tanshinone II A stabilizes}

vulnerable plaques by suppressing RAGE signaling and NF-kappaB activation in apolipoproteinE-deficient mice. Mol Med Rep. 2016;14:4983-4990.

24. Harja E, Bu DX, Hudson BI, Chang JS, Shen X, Hallam K, Kalea AZ, Lu Y, Rosario RH, Oruganti S, Nikolla Z, Belov D, Lalla E, Ramasamy R, Yan SF and Schmidt AM. Vascular and inflammatory stresses mediate atherosclerosis via RAGE and its ligands in apoE-/- mice. J Clin Invest. 2008;118:183-94.

25. Bro S, Flyvbjerg A, Binder CJ, Bang CA, Denner L, Olgaard K and Nielsen LB. A neutralizing antibody against receptor for advanced glycation end products (RAGE) reduces atherosclerosis in uremic mice. Atherosclerosis. 2008;201:274-80.

26. Ikeda K, Higashi T, Sano H, Jinnouchi Y, Yoshida M, Araki T, Ueda S and Horiuchi S. N (epsilon)-(carboxymethyl)lysine protein adduct is a major immunological epitope in proteins modified with advanced glycation end products of the Maillard reaction. Biochemistry. 1996;35:8075-83.

27. Belmokhtar K, Ortillon J, Jaisson S, Massy ZA, Boulagnon Rombi C, Doue M, Maurice P, Fritz G, Gillery P, Schmidt AM, Rieu P and Toure F. Receptor for advanced glycation end products: a key molecule in the genesis of chronic kidney disease vascular calcification and a potential modulator of sodium phosphate co-transporter PIT-1 expression. Nephrol Dial Transplant. 2019.

28. Adam F, Khatib AM, Lopez JJ, Vatier C, Turpin S, Muscat A, Soulet F, Aries A, Jardin I, Bobe R, Stepanian A, de Prost D, Dray C, Rosado JA, Valet P, Feve B and Siegfried G. Apelin: an antithrombotic factor that inhibits platelet function. Blood. 2016;127:908-20. 
29. Gorisse L, Pietrement C, Vuiblet V, Schmelzer CE, Kohler M, Duca L, Debelle L, Fornes P, Jaisson S and Gillery P. Protein carbamylation is a hallmark of aging. Proc Natl Acad Sci US A. 2016;113:1191-6.

30. Li W, McIntyre TM and Silverstein RL. Ferric chloride-induced murine carotid arterial injury: A model of redox pathology. Redox Biol. 2013;1:50-5.

31. Semba RD, Fink JC, Sun K, Windham BG and Ferrucci L. Serum carboxymethyl-lysine, a dominant advanced glycation end product, is associated with chronic kidney disease: the Baltimore longitudinal study of aging. J Ren Nutr. 2010;20:74-81.

32. Foell D, Ichida F, Vogl T, Yu X, Chen R, Miyawaki T, Sorg C and Roth J. S100A12 (ENRAGE) in monitoring Kawasaki disease. Lancet. 2003;361:1270-2.

33. London GM and Drueke TB. Atherosclerosis and arteriosclerosis in chronic renal failure. Kidney Int. 1997;51:1678-95.

34. Jin X, Yao T, Zhou Z, Zhu J, Zhang S, Hu W and Shen C. Advanced Glycation End Products Enhance Macrophages Polarization into M1 Phenotype through Activating RAGE/NFkappaB Pathway. Biomed Res Int. 2015;2015:732450.

35. Liabeuf S, Drueke TB and Massy ZA. Protein-bound uremic toxins: new insight from clinical studies. Toxins (Basel). 2011

3:911-9.

36. Gawlowski T, Stratmann B, Ruetter R, Buenting CE, Menart B, Weiss J, Vlassara H, Koschinsky T and Tschoepe D. Advanced glycation end products strongly activate platelets. Eur J Nutr. 2009;48:475-81.

37. Herczenik E, Bouma B, Korporaal SJ, Strangi R, Zeng Q, Gros P, Van Eck M, Van Berkel TJ, Gebbink MF and Akkerman JW. Activation of human platelets by misfolded proteins. Arterioscler Thromb Vasc Biol. 2007;27:1657-65. 
38. Zhu W, Li W and Silverstein RL. Advanced glycation end products induce a prothrombotic phenotype in mice via interaction with platelet CD36. Blood. 2012;119:6136-44.

39. Ahrens I, Chen YC, Topcic D, Bode M, Haenel D, Hagemeyer CE, Seeba H, Duerschmied D, Bassler N, Jandeleit-Dahm KA, Sweet MJ, Agrotis A, Bobik A and Peter K. HMGB1 binds to activated platelets via the receptor for advanced glycation end products and is present in platelet rich human coronary artery thrombi. Thromb Haemost. 2015;114:994-1003. 40. Bruchfeld A, Qureshi AR, Lindholm B, Barany P, Yang L, Stenvinkel P and Tracey KJ. High Mobility Group Box Protein-1 correlates with renal function in chronic kidney disease (CKD). Mol Med. 2008;14:109-15.

41. Yago T, Liu Z, Ahamed J and McEver RP. Cooperative PSGL-1 and CXCR2 signaling in neutrophils promotes deep vein thrombosis in mice. Blood. 2018;132:1426-1437.

42. Naganuma T, Tsujita K, Mitomo S, Ishiguro H, Basavarajaiah S, Sato K, Kobayashi T, Obata J, Nagamatsu S, Yamanaga K, Komura N, Sakamoto K, Yamamoto E, Izumiya Y, Kojima S, Kaikita K, Ogawa H and Nakamura S. Impact of Chronic Kidney Disease on Outcomes After Percutaneous Coronary Intervention for Chronic Total Occlusions (from the Japanese Multicenter Registry). Am J Cardiol. 2018;121:1519-1523.

43. Sato T, Hatada K, Kishi S, Fuse K, Fujita S, Ikeda Y, Takahashi M, Matsubara T, Okabe $\mathrm{M}$ and Aizawa Y. Comparison of clinical outcomes of coronary artery stent implantation in patients with end-stage chronic kidney disease including hemodialysis for three everolimus eluting (EES) stent designs: Bioresorbable polymer-EES, platinum chromium-EES, and cobalt chrome-EES. J Interv Cardiol. 2018;31:170-176.

44. Chitalia VC, Shivanna S, Martorell J, Balcells M, Bosch I, Kolandaivelu K and Edelman ER. Uremic serum and solutes increase post-vascular interventional thrombotic risk through altered stability of smooth muscle cell tissue factor. Circulation. 2013;127:365-76. 
45. Jain N, Li X, Adams-Huet B, Sarode R, Toto RD, Banerjee S and Hedayati SS.

Differences in Whole Blood Platelet Aggregation at Baseline and in Response to Aspirin and Aspirin Plus Clopidogrel in Patients With Versus Without Chronic Kidney Disease. Am J Cardiol. 2016;117:656-663. 


\section{TABLES}

Table 1. Biological characteristics

Data are reported as mean \pm SEM. RBC, red blood cell; Hb, hemoglobin; Hct, hematocrit, ${ }^{*} \mathrm{p}<0.05 ; * * \mathrm{p}<0.01 ; \mathrm{ns}$, non-significant.

\begin{tabular}{|c|c|c|c|c|c|c|c|c|c|c|c|c|c|}
\hline \multirow[b]{2}{*}{ Urea (mmol/L) } & \multicolumn{5}{|c|}{$\begin{array}{l}\text { Apoe }^{-/-} \\
\text {Sham }\end{array}$} & \multicolumn{8}{|c|}{ Apoe $^{-/-} /$Ager $^{-/-}$} \\
\hline & $9.8=$ & $\pm \quad 0.43$ & 23.7 & \pm 2.1 & $* *$ & 9.4 & \pm & $\mathbf{0 . 4}$ & & 21. & \pm & $=1.7$ & $* *$ \\
\hline Creatinine $(\mu \mathrm{mol} / \mathrm{L})$ & $10.9=$ & $\pm \quad 0.73$ & 22.8 & \pm 1.3 & $*$ & 11. & \pm & 0.7 & & 17. & \pm & 2.2 & $*$ \\
\hline Triglyceride (mmol/L) & $0.9=$ & $\pm \quad 0.04$ & 1.4 & \pm 0. & ns & 1.1 & & 0.1 & \# & 1.2 & \pm & 0.1 & ns \\
\hline Cholesterol (mmol/L) & $8.2=$ & $\pm \quad 0.73$ & 16.0 & \pm 1.5 & $* *$ & 9.1 & $x$ & 0.9 & & 14. & \pm & $=2.2$ & $* *$ \\
\hline Calcium (mmol/L) & $2.0=$ & $\pm \quad 0.09$ & 1.9 & \pm 0.1 & ns & 1.9 & 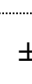 & 0.0 & & 2.2 & \pm & 0.0 & ns \\
\hline Phosphorus (mmol/L) & $2.2=$ & $\pm \quad 0.27$ & 2.6 & +0.1 & ns & 2.6 & \pm & 0.2 & & 2.8 & + & 0.1 & ns \\
\hline $\mathrm{RBC}(\mathrm{M} / \mathrm{mm} 3)$ & $7.8=$ & \pm 0.2 & 6.2 & \pm 0.2 & $*$ & 8.4 & \pm & 0.3 & & 6.6 & \pm & 0.2 & $* * * *$ \\
\hline $\operatorname{Hgb}(\mathrm{g} / \mathrm{dL})$ & $10.8=$ & $\pm \quad 0.2$ & 9.1 & \pm 0.2 & $*$ & 11. & \pm & $\mathbf{0 . 4}$ & & 8.5 & $=$ & 0.3 & $* * * *$ \\
\hline Het (\%) & $36.8=$ & $\pm \quad 0.4$ & 30.5 & \pm 0. & * & 39. & ]$^{ \pm}$ & 1.3 & & & $1 \pm$ & t 0.6 & $* * * *$ \\
\hline
\end{tabular}




\section{Table 2. Effect of RAGE deletion of the stability of platelet aggregation}

The table shows the disaggregation observed $5 \mathrm{~min}$ after stimulation with $100 \mathrm{mU} / \mathrm{mL}$ of

thrombin. Results are expressed as the percentage of disaggregation out of total aggregation.

\begin{tabular}{|c|c|c|c|c|}
\hline \multirow{2}{*}{} & \multicolumn{4}{|c|}{ Thrombin $100 \mathrm{mU} / \mathrm{mL}$} \\
\cline { 2 - 5 } & Sham & CKD & Sham & CKD \\
\hline $\begin{array}{c}\text { Disaggregation at } 5 \text { min: } \\
\%(n / t o t a l)\end{array}$ & $\begin{array}{c}12.5 \% \\
(1 / 8)\end{array}$ & $\begin{array}{c}0 \% \\
(0 / 8)\end{array}$ & $\begin{array}{c}62.5 \% \\
(5 / 8)\end{array}$ & $\begin{array}{c}0 \% \\
(0 / 4)\end{array}$ \\
\hline
\end{tabular}

\section{Table 3. Platelet characteristics}

Data are reported as mean \pm SEM, $(n=5$ to 9). PLT: platelets. MPV: mean platelet volume

\begin{tabular}{|c|c|c|c|c|}
\hline & $\begin{array}{l}\text { Apoe }^{-/-} \\
\text {Sham }\end{array}$ & CKD & $\begin{array}{l}\text { Apoe } \text { - }^{-/-} \text {Ager }^{-/-} \\
\text {Sham }\end{array}$ & CKD \\
\hline PLT (m/mm3) & $1027.2 \pm 103.3$ & $1188.8 \pm 234.5$ & $1100.8 \pm 133.1$ & $1396.6 \pm 209.7$ \\
\hline MPV (fL) & \pm 0.1 & \pm 0.1 & \pm 0.1 & \pm 0.2 \\
\hline
\end{tabular}




\section{FIGURE LEGENDS}

Figure 1. CKD increases platelet activation and RAGE deletion limits these effects. (A)

Histograms of a representative flow cytometry assay to assess platelet activation via $\alpha$ II $\beta 3$ activation and surface exposure of P-selectin in whole blood for Apoe $\mathrm{Ap}^{-/-}$and $\mathrm{Apoe}^{-/ /} \mathrm{Ager}^{-/-}$mice. Platelets were labelled with PE-conjugated JON/A (left panel, top) and anti-P-selectin (left panel, down), fluorescence is represented in count per fluorescent intensity (FI). Platelet activation was induced by thrombin $(10 \mathrm{mU} / \mathrm{mL})$ and compared to basal condition. The right panel shows the mean fluorescence intensity (MFI) for each group of mice \pm SEM $\left(n=7\right.$ per group for Apoe ${ }^{-/}$ mice, $n=5$ to 8 per group for Apoe $\mathrm{e}^{-/ /} / \mathrm{Ager}^{-/-}$mice). ${ }^{*} \mathrm{p}<0.05$. (B) Platelet aggregation was measured in whole blood by impedance using a Multiplate analyzer ${ }^{\circledR}$. Platelet aggregation was induced by $5 \mu \mathrm{M}$ ADP or $2.5 \mu \mathrm{g} / \mathrm{mL}$ collagen. The bar graph shows the mean amplitude of aggregation expressed as the area under the curve $\left(\mathrm{AUC}^{*} \min \right) \pm \mathrm{SEM}\left(n=6\right.$ per group for $\mathrm{Apoe}^{-}$ /- and Apoe ${ }^{-/-} /$Ager $^{-/-}$mice $) .{ }^{*} \mathrm{p}<0.05 ; * * \mathrm{p}<0.01$. Representative curves from Apoe ${ }^{-/-}$or Apoe ${ }^{-/-}$ /Ager $^{-/-}$uremic (CKD) mice (in grey) and Apoe - $^{--}$or Apoe A $^{-/ /}$Ager $^{-/-}$sham mice (in black) are shown in the left panel. (C) Platelet aggregation was measured in platelet-rich plasma by turbidimetry using a Sodere ${ }^{\circledR}$ aggregometer. Platelet aggregation was induced by 50 or 100 $\mathrm{mU} / \mathrm{mL}$ thrombin. The bar graph shows the mean amplitude of aggregation expressed as a percentage of light transmission using control $\mathrm{PPP} \pm \mathrm{SEM}\left(n=8\right.$ per group for Apoe ${ }^{-/-}$mice, $n=$ 4 per group for Apoe $\mathrm{A}^{-/ /} \mathrm{Ager}^{-/-}$mice). ${ }^{*} \mathrm{p}<0.05 ; * * \mathrm{p}<0.01$; NS, non-significant. Representative

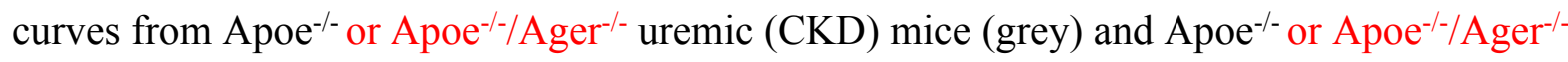
sham mice (black) are shown in the left panel. Scale bar: 1 minute. 


\begin{abstract}
Figure 2. Platelet receptor cell surface expression. Surface expression of $\alpha_{2}, \mathrm{GPIb}_{\alpha}, \mathrm{GPIb}_{\beta}$, GPVI, $\alpha_{\text {IIb }}$, and GPIV in each group of mice determined by flow cytometry with FITCconjugated anti-mouse $\alpha_{2}$ mAb (Sam.G4), GPIb ${ }_{\beta}$ mAb (Xia.C3), GPVI mAb (JAQ1), and $\alpha_{\text {IIb }}$ mAb (MWReg30) and PE-conjugated anti-mouse CD36 mAb (CRF D-2712) and GPIb $\mathrm{mAb}_{\alpha}$ (Xia.B2). Results are expressed as the mean fluorescence intensity (MFI) relative to isotype controls MFI (MFI mAb - MFI isotypes) $\pm \operatorname{SEM~(~} n=3$ per group).
\end{abstract}

\author{
Figure 3. Uremia and RAGE deletion have no effect on washed platelet function. (A) Platelet \\ aggregation was induced by 25,50 , or $100 \mathrm{mU} / \mathrm{mL}$ of thrombin. The bar graphs show the mean \\ amplitude of aggregation expressed as the percentage of light transmission using Tyrode buffer \\ alone as a control $\pm \operatorname{SEM}\left(n=3\right.$ per group) for Apoe $^{-/-}$and Apoe Aper $^{-/-}$Ager $^{-/}$mice. Activation of \\ $\alpha_{\mathrm{IIb}} \beta_{3}(\mathbf{B})$ and surface exposure of P-selectin $(\mathbf{C})$ of washed platelets were determined by flow \\ cytometry after addition of 25 or $50 \mathrm{mU} / \mathrm{mL}$ of thrombin. The lefts panels show a representative

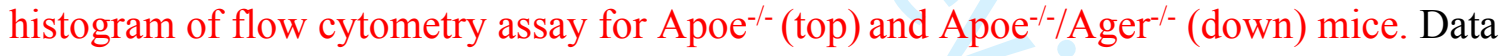 \\ represent the mean fluorescent intensity $(\mathrm{MFI}) \pm \operatorname{SEM}(n=3$ per group).
}

\footnotetext{
Figure 4. RAGE ligands accumulate during uremia and are involved in uremia-induced platelet hyperactivation. (A) Serum samples were collected from Apoe And Apoe $^{-/ /}$/Ager ${ }^{-/-}$ sham and CKD mice and the CML concentration was determined by LC-MS/MS. Results are expressed as the ratio of CML concentration to total lysine concentration $(\mathrm{mmol} / \mathrm{mol}) ; * * \mathrm{p}<0.01$; NS, non-significant. $(\mathbf{B}, \mathbf{C})$ Washed platelets from Apoe And Apoe $^{-/-}$ager Ager $^{-/}$mice were incubated with RAGE ligands for $10 \mathrm{~min}$ (before the arrow) and then assessed for aggregation in response to $25 \mathrm{mU} / \mathrm{mL}$ of thrombin (indicted by the arrow). Representative curves from different
} 
conditions are shown in the top panels. Scale bar: 5 minutes. (B) Platelets were incubated with glycated-HSA (G) or non-glycated-HSA (NG-HSA) as a control. The bar graphs show the aggregation results expressed as the mean percentage of the amplitude of aggregation (i.e. maximal aggregation of each condition normalized to the control condition $\pm \operatorname{SEM}(n=3$ per group). ${ }^{*} \mathrm{p}<0.05$. (C) Platelets were incubated with increasing concentrations of S100A12. The bar graph shows the aggregation results expressed as mean percentage of the amplitude of aggregation (i.e. maximal aggregation of each condition normalized to the control condition \pm $\operatorname{SEM}\left(n=3\right.$ to 5 per group). ${ }^{*} \mathrm{p}<0.05 ; * * \mathrm{p}<0.01$.

\section{Figure 5. Uremia accelerates arterial thrombus formation and RAGE deletion provides}

protection. (A) Representative images of the progression of thrombus formation induced by $\mathrm{FeCl}_{3}$ injury to the carotid artery of Apoe ${ }^{-/-}$and $\mathrm{Apoe}^{-/-} / \mathrm{Ager}^{-/}$sham or CKD mice. Mice were injected with Rhodamine $6 \mathrm{G}(4 \mathrm{mg} / \mathrm{kg})$, and thrombus development and complete vessel occlusion were monitored in real time, under a microscope, after application of a patch containing 7.5\% $\mathrm{FeCl}_{3}$. (B) Dot plots showing the time to complete occlusion for each animal. Means are indicated by the horizontal bars $\pm \operatorname{SEM}\left(n=5\right.$ to 8 per group). ${ }^{*} \mathrm{p}<0.05 ;{ }^{*} \mathrm{p}<0.01$; $* * * * \mathrm{p}<0.0001$; NS, non-significant. Time scale is expressed in minutes. (C) Embolic carotids observed during thrombus formation. Results are expressed as the percentage of carotids with reported emboli out of the total analyzed carotid arteries. 
Figure 1 Ortillon et al.

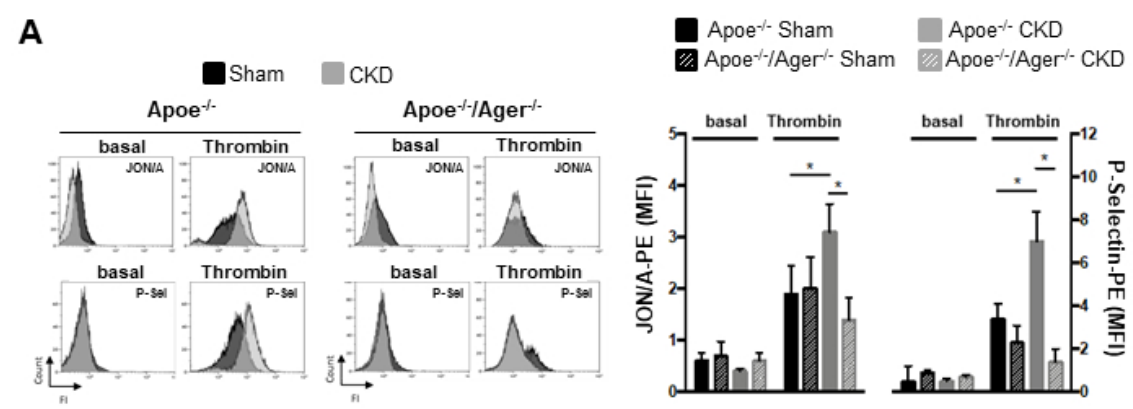

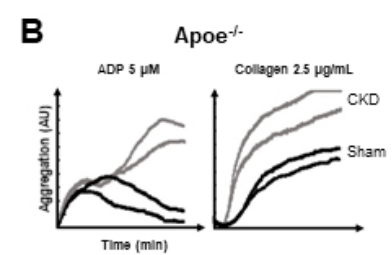

Apoe ${ }^{-/} /$Ager $^{-/}$

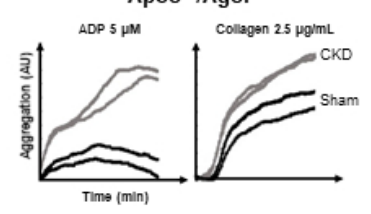

C

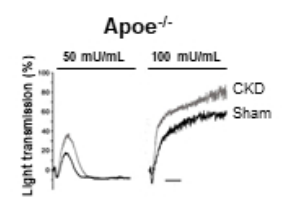

Apoe ${ }^{-1} /$ Ager ${ }^{-1}$

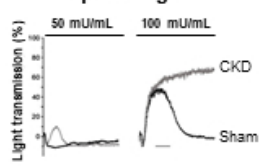

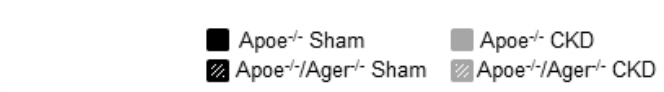

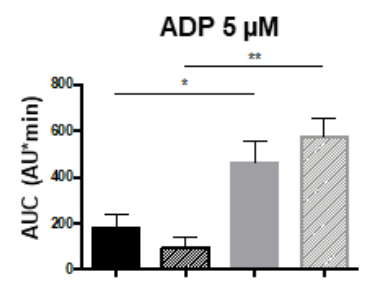

Collagen $2.5 \mu \mathrm{g} / \mathrm{mL}$

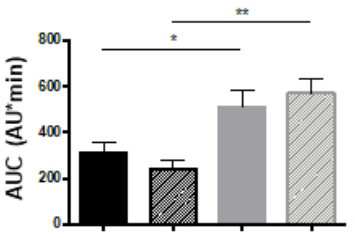

Apoe- Apoe $^{-/-}$CKD

W Apoe $^{-/ /} /$Ager $^{/-}$Sham Apoe $^{-/ /} /$Ager $^{/-}$CKD

Thrombin $50 \mathrm{mU} / \mathrm{mL} \quad$ Thrombin $100 \mathrm{mU} / \mathrm{mL}$
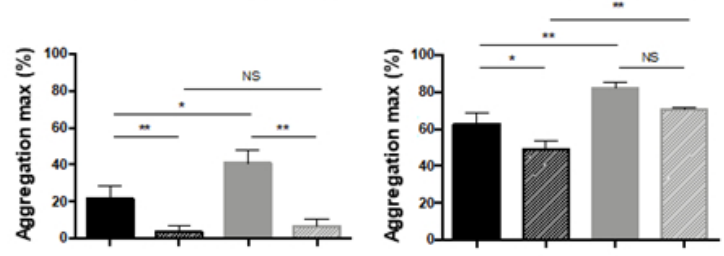

revised_figure_1

$190 \times 254 \mathrm{~mm}(96 \times 96 \mathrm{DPI})$ 
Figure 2 Ortillon et al.

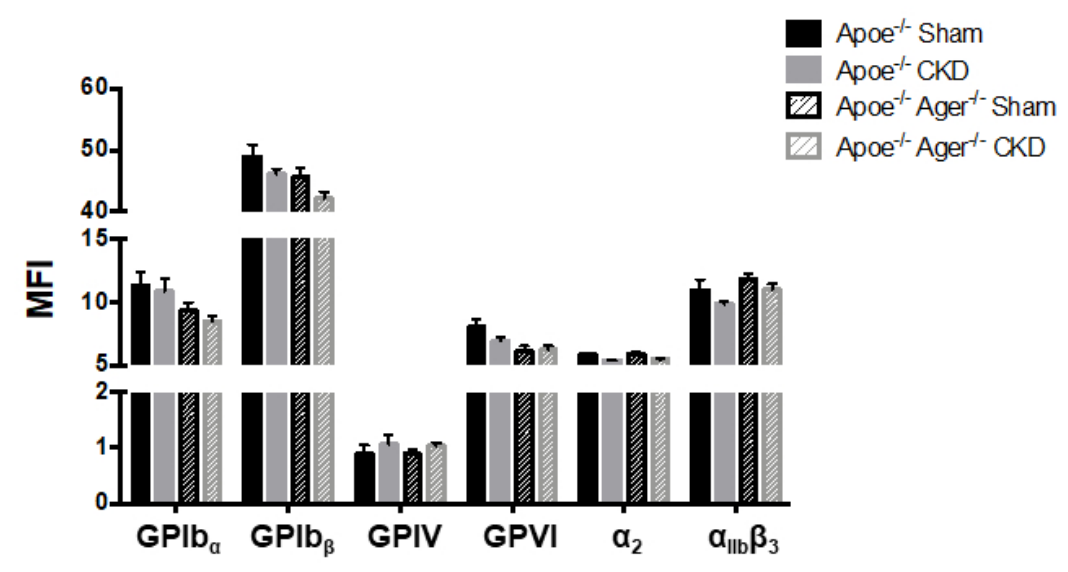

revised_figure_2

$190 \times 254 \mathrm{~mm}(96 \times 96 \mathrm{DPI})$ 
Figure 3 Ortillon et al.

A

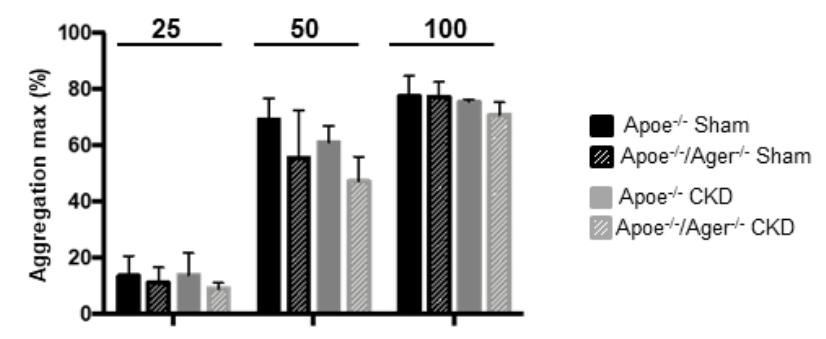

B
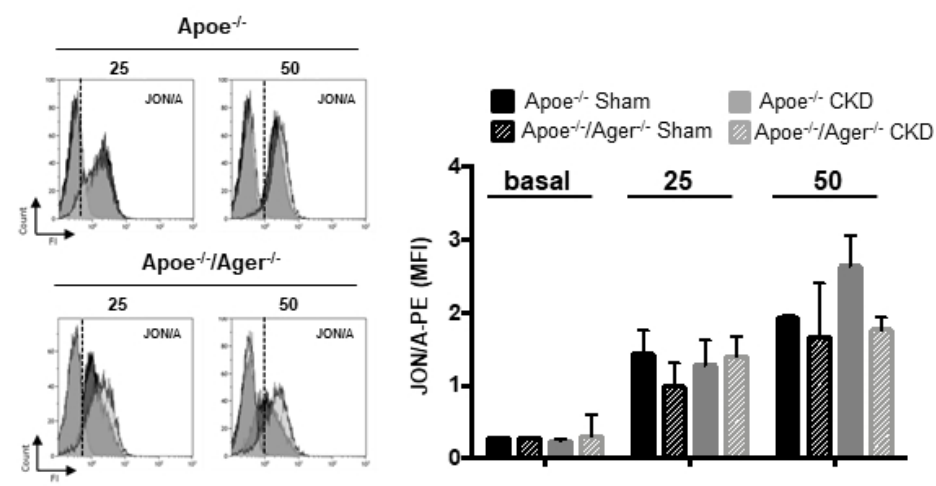

c
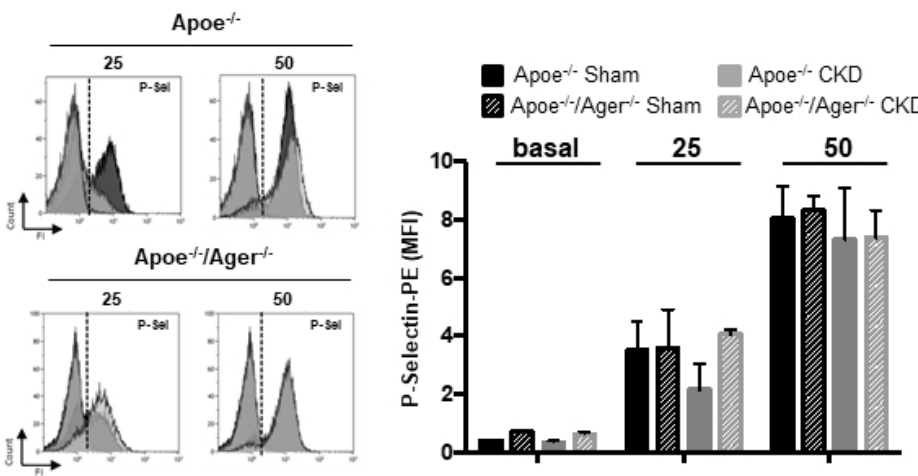

revised_figure_3

$190 \times 254 \mathrm{~mm}(96 \times 96 \mathrm{DPI})$ 
Figure 4 Ortillon et al.

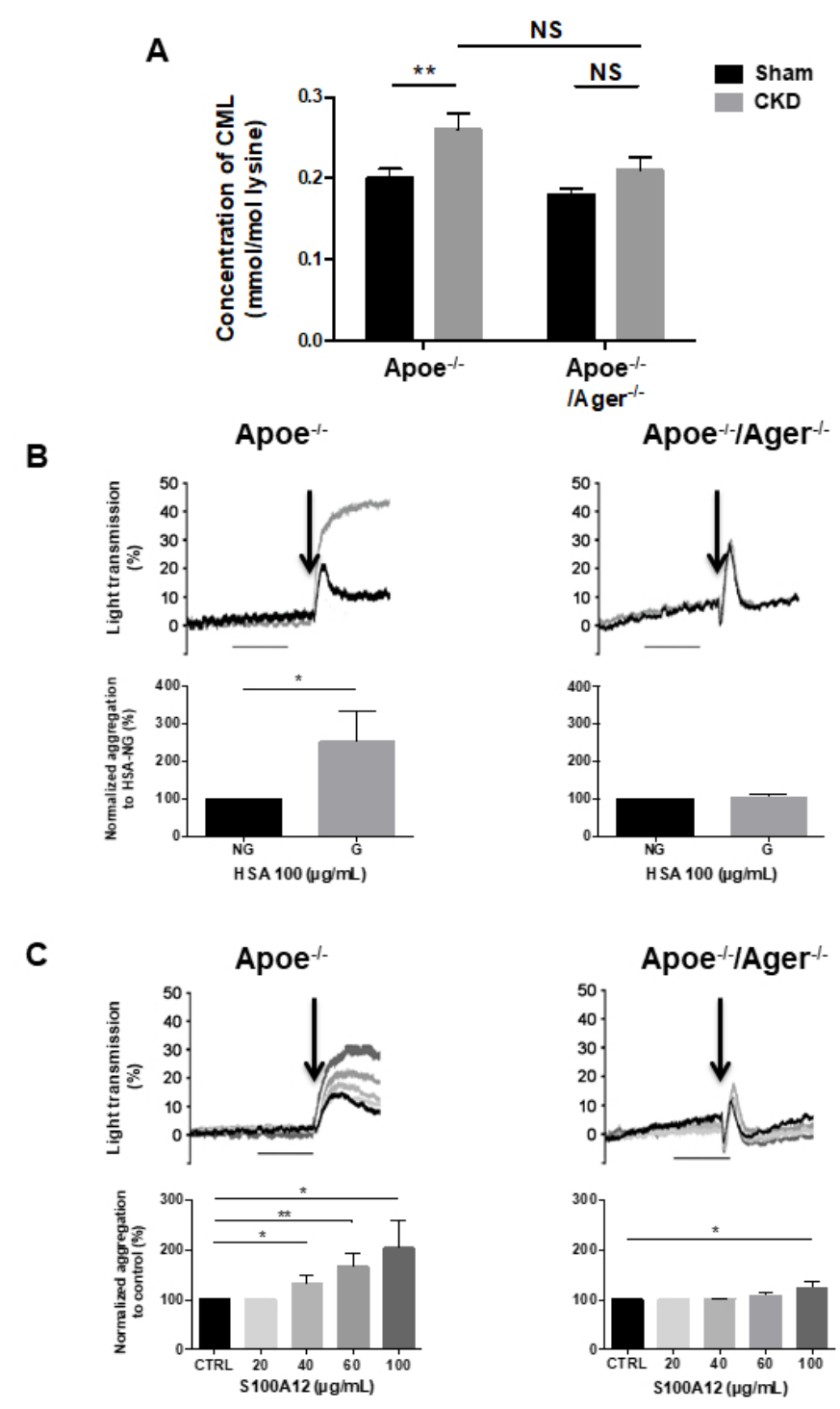

revised_figure_4

$190 \times 254 \mathrm{~mm}(96 \times 96 \mathrm{DPI})$ 
Figure 5 Ortillon et al.
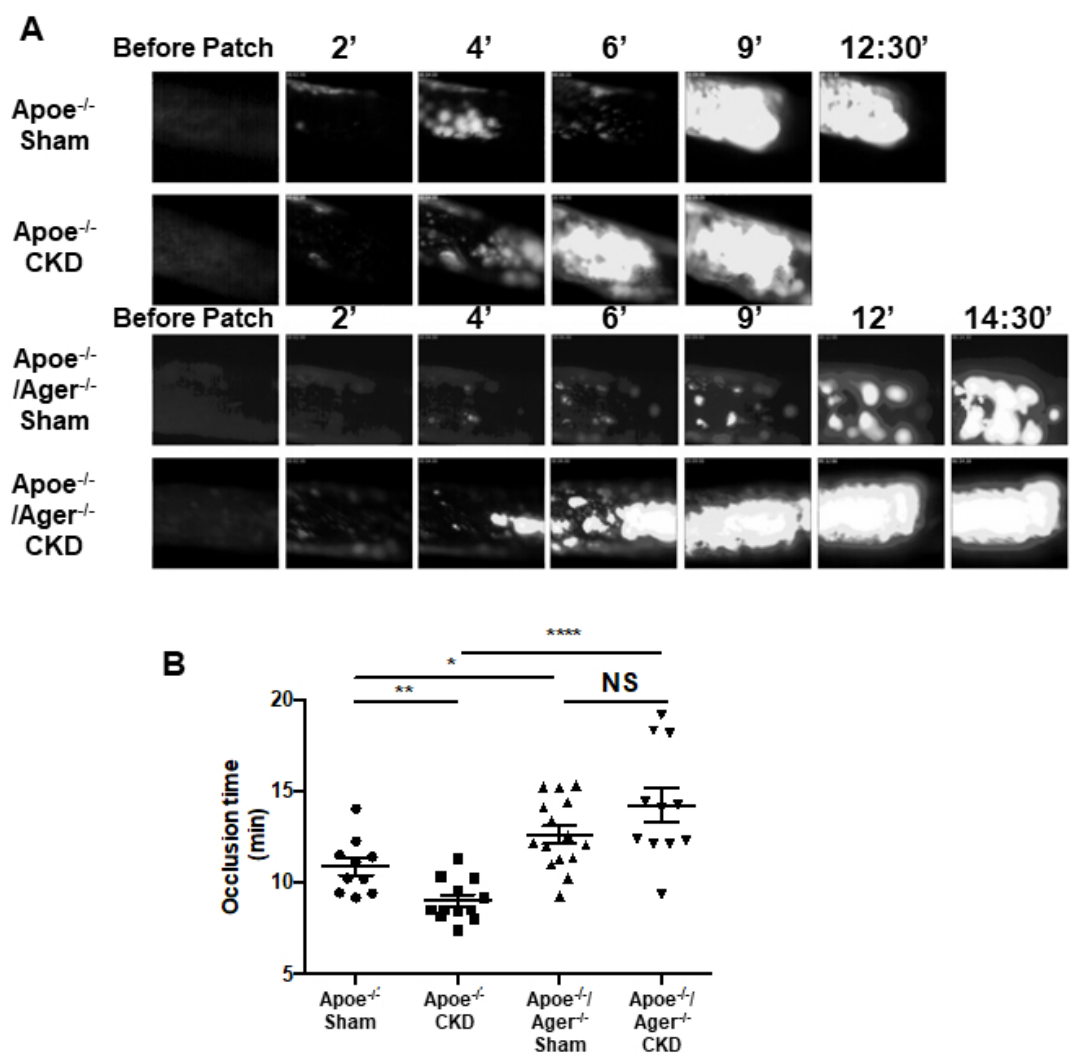

C

\begin{tabular}{|c|c|c|c|c|}
\hline \multirow{2}{*}{} & \multicolumn{2}{|c|}{ Apoe-- $^{-1-}$} & \multicolumn{2}{c|}{ Apoe $^{-1-1}$ Ager $^{-1-}$} \\
\cline { 2 - 5 } & Sham & CKD & Sham & CKD \\
\hline $\begin{array}{c}\text { Percentage of carotids } \\
\text { showing embols before } \\
\text { occlusion \% (nb/total) }\end{array}$ & $30(3 / 10)$ & $8,3(1 / 12)$ & $26,7(4 / 15)$ & $54,5(6 / 11)$ \\
\hline
\end{tabular}

revised_figure_5

$190 \times 254 \mathrm{~mm}(96 \times 96 \mathrm{DPI})$ 